\title{
Rapeseed proteins - Production methods and possible application ranges
}

\section{Daniela Von Der Haar ${ }^{\star}$, Klaus Müller, Stephanie Bader-Mittermaier and Peter Eisner}

Department of Process Engineering, Fraunhofer Institute for Process Engineering and Packaging, Giggenhauser Str. 35, 85354 Freising, Germany

Received 30 August 2013 - Accepted 9 September 2013

\begin{abstract}
The worldwide increasing demand in proteins for human nutrition and animal feeding leads to a growing interest in novel protein sources. Therefore, rapeseed as an established raw material for the production of edible oils could be a promising alternative, as large amounts of press cakes and residues of oil extraction are available. Integrated fractionizing processes for simultaneous oil and protein isolation using aqueous-alcoholic extraction or adsorption techniques open many opportunities for new protein ingredients from rapeseed. The present manuscript compares two strategies to identify a suitable process for achieving highly functional ingredients for the use in food applications such as sausages, bakery products or mayonnaise. One process was based on hulling of the rapeseed kernels followed by an aqueous-alcoholic-extraction of the de-oiled flour. Based on this process, protein ingredients with about $60 \%$ protein content, but only poor functional properties could be produced. The application concentration of this ingredient was limited to $2 \%$, because of oily and strawy off-flavors. Isolates with protein contents higher than $90 \%$ and improved sensory and functional properties could be achieved with an aqueous extraction followed by adsorption of secondary plant metabolites on specific resins and an ultrafiltration of the aqueous extract. This process enables the production of protein isolates with reduced off-flavors and optimized functional profiles. In several food applications a very promising utilization potential of these ingredients could be confirmed.
\end{abstract}

Keywords: Food ingredients / plant protein / rapeseed / extraction / techno-functional properties

\begin{abstract}
Résumé - Protéines de colza : méthodes de production et champs d'application potentiels. La demande mondiale croissante en protéines destinées à l'alimentation humaine et animale génère un intérêt grandissant pour les nouvelles sources de protéines. Aussi, la graine de colza, en tant que matière première utilisée de longue date pour la production d'huiles comestibles, pourrait représenter une alternative prometteuse, puisque de grandes quantités de tourteaux et de résidus d'extraction de l'huile sont disponibles. Les process de fractionnement intégré pour isoler simultanément l'huile et la protéine, utilisant l'extraction hydro-alcoolique ou des techniques d'adsorption, ouvrent de nombreuses opportunités pour des nouveaux ingrédients protéiques issus de la graine de colza. Le manuscrit présenté compare deux stratégies d'identification d'un procédé approprié permettant de réaliser des ingrédients fortement fonctionnels pour des applications alimentaires comme les saucisses, les produits de boulangerie ou la mayonnaise. Un process est basé sur le dépelliculage de graines de colza suivi par une extraction hydro-alcoolique de la farine d'huile. Avec ce procédé, des ingrédients protéinés présentant une teneur en protéines d'environ $60 \%$, mais des propriétés fonctionnelles réduites, pourraient être produits. La concentration d'application de cet ingrédient a été limitée à $2 \%$, à causes de saveurs indésirables de gras et de paille. Des isolats avec des teneurs en protéines de plus de $90 \%$, et des propriétés sensorielles et fonctionnelles améliorées, pourraient être réalisés avec une extraction aqueuse suivie par une adsorption des métabolites végétaux secondaires sur des résines spécifiques et une ultrafiltration de l'extrait aqueux. Ce processus permet la production d'isolats de protéines avec des saveurs indésirables réduites et des profils fonctionnels optimisés. Dans plusieurs applications alimentaires, un potentiel d'utilisation très prometteur de ces ingrédients semble se confirmer.
\end{abstract}

Mots clés : Ingrédient alimentaire / protéine végétale / colza / extraction / propriétés fonctionnelles et technologiques

\footnotetext{
^ Correspondence:

Daniela.von.der.haar@ivv.fraunhofer.de
} 


\section{Introduction}

Food producers and scientists are looking for alternative protein sources due to the increasing demand of protein foods worldwide. Besides, the scientific and economic interest for the cultivation and the processing of rapeseed is still increasing which is reflected by a $65 \%$ increase of rapeseed production from $38 \mathrm{mt}$ in 2000 to $62.5 \mathrm{mt}$ in 2011 ( $c f$. FAOSTAT, http://faostat.fao.org, 2013). This underlines the importance of rapeseed as being the second leading source for vegetable oils in the world behind soybean.

Generally, rapeseed contains about 40 to $45 \%$ of oil having a high amount of unsaturated essential fatty acids. The oil content of the flours is reduced to approximately $3 \%$ by industrial de-oiling using hexane. Besides fat, de-oiled rapeseed flour consists of high amounts of proteins (35-40\%), and carbohydrates (30-35\%), as well as crude fibers (10-15\%), minerals (5-10\%) and secondary plant metabolites (up to 10\%).

The most abundant constituents of the secondary plant metabolites in rapeseed are phenolic compounds including tannins, as well as glucosinolates and phytic acid. Altogether, these secondary plant metabolites are known to reduce the nutritive quality of rapeseed flours and impair their functional and sensory characteristics (Jones, 1979; Mieth et al., 1983; Harland and Morris, 1995; Shahidi et al., 1997; Porres et al., 2001). Phenolic acids and tannins constitute to approximately $50 \%$ of these compounds being located in the hulls. Phenolic compounds, for instance, cause a bitter and astringent after-taste along with a dark color of the products (Synge, 1975; Sosulski, 1979; Naczk et al., 1986), as they are able to form irreversible complexes with proteins (Mieth et al., 1983; Naczk and Shahidi, 1989). Sinapic acid and its derivatives like sinapine comprise app. $73 \%$ of the phenolic compounds present in rapeseed flour and therefore, are the most abundant phenolic compounds (Naczk and Shahidi, 1989). Phytic acid, which is mainly present as calcium, magnesium or potassium phytate, amounts to 1 to $6 \%$ in rapeseeds. Phytates can form complexes with proteins and hence, decrease protein functionality as reported by Schwenke (Schwenke, 1994). Besides, the presence of high amounts of phytate also hinders the absorption of minerals from food. Furthermore, the presence of glucosinolates in rapeseed flours has been extensively reduced by breeding of so-called double-zero varieties. The de-oiled flours of these varieties have glucosinolate concentrations below the critical value of $30 \mu \mathrm{mol} / \mathrm{g}$. (Bell, 1984; Shahidi et al., 1997) However, in aqueous solutions applied during protein recovery an enzymatic hydrolysis of the glucosinolates to isothiocyanate, nitrile, and thiocyanate among others by myrosinase is possible after disintegration of the rapeseed cells. The resulting compounds interact with rapeseed proteins and reduce their nutritive value (Mieth et al., 1983; Bell, 1984; Huang, 1994).

In addition to the secondary plant metabolites, proteins are important substances present in de-oiled rapeseed flours with up to $40 \%$. Native rapeseed proteins consist of about a total of 40 different protein fractions. However, only the three main fractions (cruciferin, napin and oleosines) are described in detail below.

Cruciferin, which amounts to app. $50 \%$ of the total protein, is a salt soluble globulin with a molecular weight of about $300 \mathrm{kDa}$. It has a sedimentation coefficient of about $12 \mathrm{~S}$ and its structure is comparable to other $11 \mathrm{~S}$ globulins like glycinin from soybeans or helianthinin from sunflower seeds. In contrast to other plant globulins, the isoelectric point of cruciferin is at neutral pH (7.25) (Schwenke et al., 1983).

Napin amounting to app. 20 to $40 \%$ of the rapeseed protein is an aqueous soluble albumin fraction consisting of 6 or 7 different sub-fractions having sedimentation coefficients of about $2 \mathrm{~S}$. It possesses a molecular weight of 12-14 kDa consisting of two polypeptide chains linked with disulfide bonds and has an isoelectric point higher than $\mathrm{pH} 10$ (Schwenke et al., 1973).

Oleosines are membrane proteins stabilizing the oleosomes within intact rapeseed cells. These exhibit a molecular weight of $20 \mathrm{kDa}$ and represent approximately 6 to $8 \%$ of the rapeseed proteins. They are insoluble in aqueous solutions due to their hydrophobic character (Murphy, 1993). Altogether, compared to other plant proteins rapeseed proteins contain the often limited amino acids cysteine and methionine in a balanced proportion to lysine and other essential amino acids (Jones, 1979; Shahidi et al., 1997). Hence, rapeseed proteins comprise high nutritive potential after extensive removal of the aforementioned secondary plant metabolites which not only impair the sensory characteristics, but also the nutritive quality of rapeseed proteins.

For food applications also the functional properties of proteins are decisive. These properties are determined by intrinsic factors like their conformational structure, their amino acid sequence as well as extrinsic factors like $\mathrm{pH}$ of the solution, ionic strength, and temperature, respectively, and should be taken into consideration during process development.

Several aqueous and aqueous-alcoholic protein recovery procedures from rapeseed flours have already been described in literature (Rubin et al., 1988; Behlau, 1990; Wäsche, 2001). These processes for the production of rapeseed protein concentrates and isolates revealed products with high contents of phenolic compounds, and therefore, bitter and adstringent aftertaste as well as an undesired, dark color. Hence, these products were not suitable for applications in feed or food. Further processes included the reduction of glucosinolates and phenolic compounds using a combination of methanol, ammonia and hexane for de-oiling (Naczk et al., 1985; Naczk et al., 1986; Rubin et al., 1988; Naczk and Shahidi, 1989). By applying this combination of solvents glucosinolates and phenolic compounds were reduced to $1.6 \mu \mathrm{mol} / \mathrm{g}$ and to $5 \mathrm{mg} / \mathrm{g}$, respectively. The de-oiled rapeseed flours prepared by this process were characterized by a light color and a neutral taste according to the researchers. Despite these results, this technique has not been implemented into industrial scale due to the relatively high costs. Therefore, the adaption and development of novel processes including alternative separation procedures should focus on the extensive removal of phenolic acids and phytates to receive highly functional protein ingredients with high nutritive quality (Cheryan, 1980; Graf, 1983; Mieth et al., 1983; Serraino and Thompson, 1984; Thompson, 1987).

Altogether, the present manuscript focusses on the comparison of different process strategies for the production of light colored rapeseed protein isolates having high nutritive value. The investigated isolation procedures comprised either 


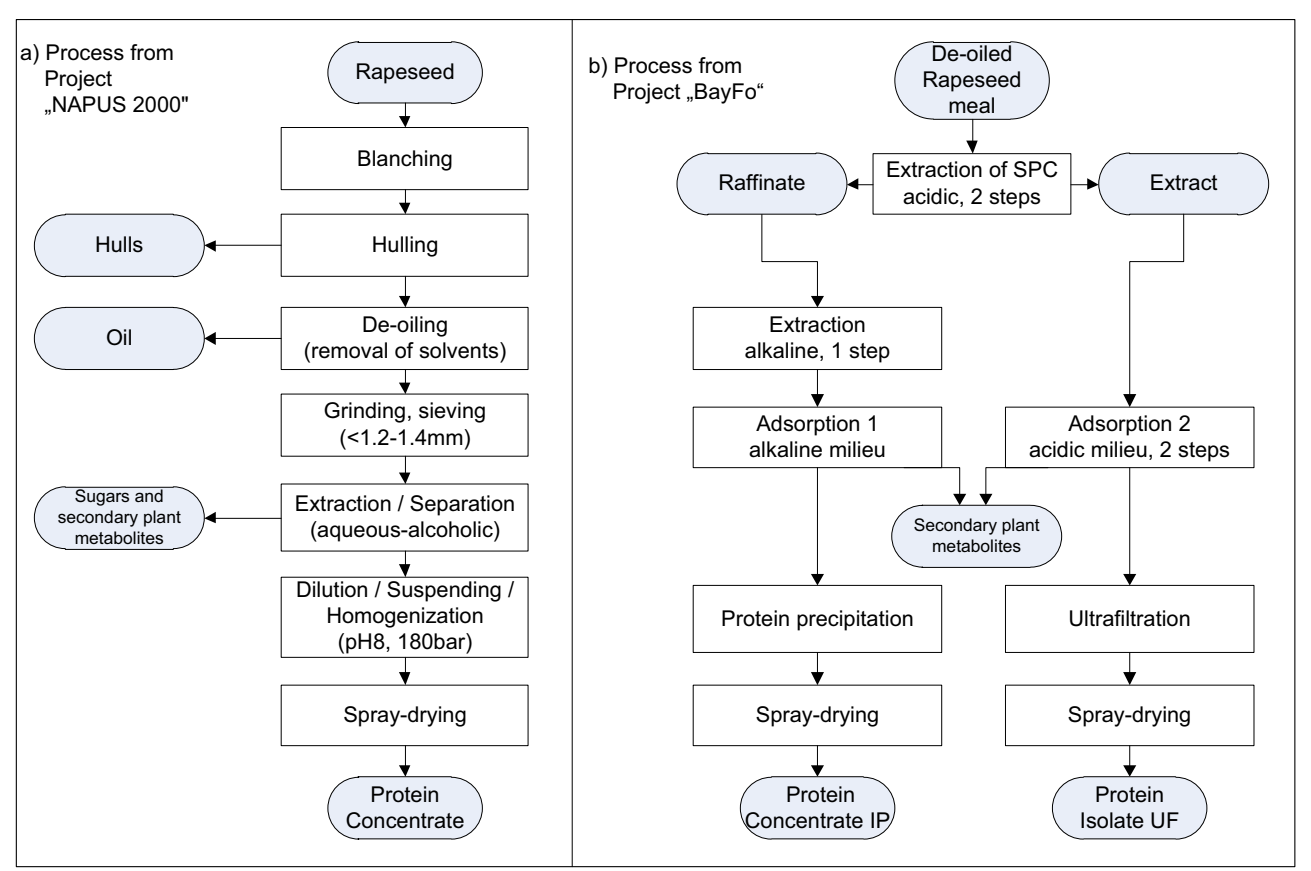

Fig. 1. Flowcharts of protein extraction processes developed in NAPUS 2000 (1a) and BayFo (1b).

a simultaneous de-oiling and protein extraction step, aqueous ethanol extraction or aqueous processing with adapted separation processes as described in the results section.

\section{Results}

\subsection{Rapeseed protein concentrate}

The fractionation of transgenic rapeseed and the simultaneous extraction of oil and high quality proteins for the application in foodstuff were investigated in the German BMBF project NAPUS 2000 (Borcherding, 2005). The obtained rapeseed protein concentrates were evaluated on basis of their techno-functional properties, their sensory characteristics like color and taste as well as their suitability for application in sausages.

A considerable reduction of more than $80 \%$ of the rapeseed oil was achieved by utilizing water-alcohol mixtures for a simultaneous oil and protein extraction based on the friolex process (Frische et al., 1996). However, the residual oil content of the protein concentrates was still $\sim 18 \%$, whereas the protein content only amounted to $47 \%$. Despite the considerable reduction of oil, the obtained rapeseed protein concentrate was not suitable for the application in food due to its high oil and low protein content. In order to facilitate the oil extraction, enzymatic processes to degrade the cell walls were investigated. Unfortunately, this degradation led to three different phases during separation consisting of an oil phase, an intermediate phase containing secondary plant metabolites, protein and oil and a solid phase, respectively.

In summary neither the aqueous-alcoholic nor the aqueousenzymatic process could meet the requirements for a simultaneous production of high quality oil and protein ingredients. Consequently, further studies coupled conventional de-oiling procedures with an aqueous-alcoholic extraction of the residue to receive high quality protein-enriched food ingredients. Besides, the production process should ensure the removal of glucosinolates, mustard oils, phytic acid and phenolic compounds, which are known to reduce the nutritional quality of rapeseed protein products as well as their sensory acceptance (Jones, 1979; Shahidi et al., 1997).

The final process developed during the NAPUS Project is shown in Figure 1a. First step is the blanching of rapeseeds to inactivate the myrosinase, which degrades glucosinolates. Moreover, a reduction of glucosinolates and sinapic acid could be reached during this kind of thermal treatment. Subsequently, the seeds were hulled which led to the removal of phenolic compounds mainly concentrated in the hulls, and milled to fine flour prior to de-oiling with hexane. After de-oiling and desolventizing carbohydrates and secondary plant metabolites were extracted using aqueous isopropyl alcohol at a concentration of $45 \%$ (w/v). The separation of phenolic compounds and glucosinolates was guaranteed by the application of a binary mixture of these polar solvents. The following downstream steps included centrifugation, high pressure homogenization and spray drying of the protein concentrate. In contrast to the aforementioned processes, the protein content of the concentrate was increased to up to $60 \%$ and the residual oil content was lower than $2 \%$. However, the alcoholic extraction affected the functional properties of the obtained concentrate and thus a re-functionalization step utilizing high pressure homogenization was necessary to receive a rapeseed protein concentrate which was suitable for the use in sausages and other food applications.

\subsection{Characterization of the protein concentrate}

For applications of proteins in sausages the technofunctional properties including gel-forming capacity (GFC), 
Table 1. Comparison of techno-functional properties of rapeseed protein concentrate (NAPUS) with and without high pressure homogenization with literature data.

\begin{tabular}{lccccc}
\hline & $\begin{array}{c}\text { Protein } \\
\text { solubility } \\
\text { at } \mathrm{pH} 4.5 \\
(\%)\end{array}$ & $\begin{array}{c}\text { Protein } \\
\text { solubility } \\
\text { at } \mathrm{pH} 7.0 \\
(\%)\end{array}$ & $\begin{array}{c}\text { Water } \\
\text { binding } \\
\text { capacity } \\
(\mathrm{ml} / \mathrm{g})\end{array}$ & $\begin{array}{c}\text { Fat } \\
\text { binding } \\
\text { capacity } \\
(\mathrm{ml} / \mathrm{g})\end{array}$ & $\begin{array}{c}\text { Emulsifying } \\
\text { capacity } \\
\text { (ml oil } / \mathrm{g} \\
\text { product) }\end{array}$ \\
\hline $\begin{array}{l}\text { Protein concentrate } \\
\text { (without homogenization) }\end{array}$ & 41 & 53 & 4.7 & 1.9 & 293 \\
\hline $\begin{array}{l}\text { Protein concentrate } \\
\text { (with homogenization) }\end{array}$ & 46 & 57 & 4.6 & 1.8 & 345 \\
\hline $\begin{array}{l}\text { Protein concentrate } \\
\text { (Thompson } \text { et al., 1982) }\end{array}$ & - & 56 & - & - & 108 \\
\hline
\end{tabular}

water- and fat-binding capacity (WBC, FBC), as well as emulsifying properties (emulsifying capacity (EC) and emulsion stability (ES)) were determined. Moreover, the influence of $\mathrm{pH}$, protein concentration, salt concentration and temperature on these properties was analyzed in detail. As mentioned before the application of alcohol in the extraction process had a negative effect on the functional properties of the protein ingredient. Thus, a re-functionalization of the ingredient was required before its application in sausages. For this purpose thermal and mechanical treatments were evaluated. In each case the final ingredients were spray-dried (Barbin et al., 2011).

Instead of improving the desired protein properties thermal treatments rather lead to inferior characteristics (data not shown), which might be attributed to further denaturation of the proteins caused by heat treatment. In contrast to these findings, the mechanical treatment by means of high pressure homogenization led to an increase of the desired protein functionalities.

Table 1 visualizes that the homogenization resulted in an increase of the EC from $293 \mathrm{ml} / \mathrm{g}$ of the untreated protein concentrate to $345 \mathrm{ml} / \mathrm{g}$. Furthermore, the protein solubility was slightly improved from $41 \%$ to $46 \%$ at $\mathrm{pH} 4.5$ and from $53 \%$ to $57 \%$ at $\mathrm{pH} 7.0$. However, no considerably influence was determined for the water and fat binding properties being similar with and without treatment.

Yoshie-Stark et al. presented a detailed summary of techno-functional properties of rapeseed meal including the influence of a steam treatment (Yoshie-Stark et al., 2006). Table 1 also presents the protein solubility and EC of a rapeseed protein concentrate produced by sodium-hexametaphosphate extraction (Liu et al., 1982; Thompson et al., 1982). Protein solubility of the concentrate is in the same range, but the EC of the homogenized concentrate developed in the NAPUS project was more than threefold higher and thus, superior to that of the concentrate reported by Thompson et al. (1982).

\subsection{Application ranges of the products}

The application of the rapeseed protein concentrates obtained with the NAPUS extraction process (Fig. 1a) was investigated in sausages. In a first experimental series the effect of protein concentrates from different rapeseed varieties on the quality of sausages was evaluated. Therefore, different concentrates obtained from Brassica napus subsp. Express, Lion and NEX were added to the sausages in amounts of $2 \%(\mathrm{w} / \mathrm{w})$ and $4.5 \%(\mathrm{w} / \mathrm{w})$, respectively. An addition of $4.5 \%$ of the rapeseed concentrates led to a dark brown coloring of the products. The protein concentrate from Brassica napus subsp. Lion was found to be the most promising for the application in sausages at a concentration of $2 \%$ because the water and fat separation was similar for the reference sausages and the sausages containing $2 \%$ rapeseed protein.

In the next step applicability of rapeseed protein concentrates as alternative for soy or lupine protein concentrates, as well as whey proteins or casein was proven. Therefore, $2 \%$ (w/w) of each protein concentrate were added to a common sausage formulation. The resulting products were examined in regard to fat and water separation, as well as their texture. Additionally, a comparative sensory evaluation was conducted.

The separation of water and oil after a 50-min heating at $105{ }^{\circ} \mathrm{C}$ indicated that $\mathrm{EC}$ and $\mathrm{WBC}$ of the samples containing rapeseed protein concentrate were comparable to the other samples. Water and oil losses amounted to approximately $1.3 \%$ for all samples, with exception for the sample prepared with whey protein concentrate having considerably higher losses of $2 \%$ resulting from lower emulsifying properties and water binding effects. The firmness of the sausages determined as breaking strength of the structure was analyzed using a texture analyzer. Sausages containing sodium caseinate and soy protein concentrate demonstrated the highest strength of 16-17 N. However, the strength of the other samples and mainly the ones containing rapeseed protein concentrates showed only slightly lower firmness $(15 \mathrm{~N})$.

The sensory tests comprised the evaluation of the cut surface of each sample, the color, the texture, the smell and the taste. Compared to the other samples the sausages containing rapeseed protein concentrates demonstrated a slightly different cut surface and also the color was slightly darker. The texture was found to be a little too soft corroborating the results of strength measured by means of a texture analyzer as described previously. Smell and taste of the sausage preparation containing the rapeseed protein concentrate were assessed to be strawy and oily.

However, in regard to its functional properties the rapeseed protein concentrate is a promising source for replacing milk and other vegetable proteins in sausages. Significant deviations from the other ingredients were obtained for the taste and color of rapeseed protein containing sausages. The improvement of the taste has been the focus of further research activities which are described below. 
Table 2. Composition of defatted rapeseed press cake, protein isolate UF and protein concentrate IP.

\begin{tabular}{lccc}
\hline & Dry matter (\%) & Protein (\%)* & Ash (\%)* \\
\hline Defatted press cake & 90.5 & 39.0 & 7.5 \\
Protein isolate UF & 95.3 & 91.2 & 1.6 \\
Protein concentrate IP & 94.0 & 80.7 & 10.0 \\
\hline
\end{tabular}

* stated in \% dry matter.

In addition to the application in sausages, baking trails were conducted aiming at a partial or even complete substitution of egg proteins by rapeseed proteins. Compared to the application in sausages similar techno-functional properties, particularly GFC and EC, are relevant for the egg replacement in bakery products due to the stabilization of dough properties and bubble formation during baking. Preliminary experiments indicated a comparable GFC between rapeseed protein concentrates and common egg ingredients (data not shown). The baking trials demonstrated that the volume expansion of pound cakes was similar in the products containing rapeseed protein concentrates compared to egg-containing references, even at a $100 \%$ substitution of egg. Similar to the sausages, the color of the rapeseed protein containing cake was slightly darker than the reference.

Summarizing, the techno-functional properties of the rapeseed protein concentrate obtained from the NAPUS extraction process were found to be suitable for application in bakery products with prospects of complete substitution of egg protein, as well as a functional ingredient in sausages to prevent water and oil separation. However, the color, as well as the flavor of the products has to be improved to reveal ingredients highly accepted by consumers.

\subsection{Rapeseed protein isolate}

In a further project funded by the Bavarian Research Fund the production of sensory improved rapeseed protein isolates and concentrates from cold pressed rapeseeds and their application in food were investigated (Müller, 2010). Before extraction, the cold pressed rapeseed cakes were further de-oiled using hexane to reduce the fat content to $\leqslant 2 \%$. The rapeseed protein products were produced using two steps (acidic preextractions and alkaline protein extractions) as shown in Figure $1 \mathrm{~b}$. In the first step, secondary plant metabolites like phytic acid and polyphenols, as well as rapeseed albumins were removed using two acidic extraction-steps. After separation, the extract was further purified using a strong base anionic resin (Purolite A $200{ }^{\circledR}$, Purolite, USA) to remove phytic acid and an anorganic adsorber resin (EXM 1694, Clariant International Ltd., Switzerland) to remove polyphenols. After removal of the secondary plant metabolites, the extract was concentrated via ultrafiltration and the retentate was spray-dried to receive a rapeseed protein isolate UF for analytical characterization and food applications. The solid phase of the acidic pre-extractions was re-extracted at alkaline $\mathrm{pH}$ to dissolve the main storage protein fractions i.e. rapeseed globulins. The dissolved proteins were precipitated at the isoelectric point, neutralized and spray-dried to receive a rapeseed protein concentrate IP.

\subsection{Characterization of the rapeseed protein preparations}

The composition of the de-oiled press cake, as well as the rapeseed protein isolate UF and the protein concentrate IP are shown in Table 2. The protein isolate UF revealed a protein content of $91.2 \%$, whereas the protein concentrate IP had $80.7 \%$ protein in dry matter. The high protein contents indicate the feasibility of the applied process for the simultaneous production of high quality rapeseed protein concentrates and isolates. Similar results were also reported by Yoshie-Stark et al. (2008). They described a fractionation process with alkaline extraction followed by isoelectric precipitation and ultrafiltration of the supernatant of the precipitate (Yoshie-Strak et al., 2008). However, the protein content of the rapeseed protein concentrate IP was significantly higher in the present study compared to the previously described results, which might be attributed to the application of acidic pre-extraction and adsorption to remove secondary plant metabolites (Yoshie-Strak et al., 2008).

The contents of essential amino acids of the rapeseed protein isolate UF and the protein concentrate IP almost achieved the values recommended by the WHO for daily intake in human beings (WHO/press 2007, Protein and amino acid requirements in human nutrition). Only the contents of cysteine and methionine in the rapeseed protein concentrate IP were below the recommended amounts. Histidine, leucine, isoleucine, valine, lysine, threonine, phenylalanine and tyrosine were present in sufficient amounts. Thus, the rapeseed ingredients of the described process are valuable resources for human nutrition and animal feed.

In addition to the overall composition, the contents of inositol phosphates (including phytic acid), glucosinolates, and sinapics have been analyzed to determine the amounts of undesirable secondary plant metabolites in the protein products (Tab. 3). The amount of glucosinolates in both the protein isolate UF and the protein concentrate IP has been reduced

Table 3. Contents of secondary plant metabolites (inositol phosphates, glucosinolates, sinapin and sinapic acid) of defatted rapeseed press cake and the protein products.

\begin{tabular}{lcccc}
\hline & $\begin{array}{c}\text { Inositol } \\
\text { phosphates } \\
(\%)\end{array}$ & $\begin{array}{c}\text { Glucosinolates } \\
(\mu \mathrm{mol} / \mathrm{g})\end{array}$ & $\begin{array}{c}\text { Sinapin } \\
(\mathrm{mg} / \mathrm{g})\end{array}$ & $\begin{array}{c}\text { Sinapic } \\
\text { acid } \\
(\mathrm{mg} / \mathrm{g})\end{array}$ \\
\hline Defatted press cake & 4.0 & 12.5 & $\mathrm{n} . \mathrm{d}$. & n.d. \\
Protein isolate UF & 0.2 & $<0.1$ & $<0.1$ & 0.3 \\
Protein concentrate IP & 5.1 & 0.3 & 0.1 & 1.4 \\
\hline
\end{tabular}


extensively by the applied extraction procedure to levels below $0.3 \mu \mathrm{mol} / \mathrm{g}$ protein, which are well below the values reported in literature and that are recommended for daily intake (Bell, 1993). Even the commercially available rapeseed protein isolates of Burcon Nutra Science Corporation (Puratein ${ }^{\circledR}$ and Supertein $\left.{ }^{\circledR}\right)$ are reported to have higher glucosinolate contents of $\geqslant 0.8 \mu \mathrm{mol} / \mathrm{g}$ depending on the protein product (Mejia et al., 2009a, 2009b). Therefore, the rapeseed protein concentrate UF and isolate IP are suitable ingredients for human nutrition and thus their application potential was evaluated. Additionally, the content of sinapin and sinapic acid was also reduced to $\leqslant 0.1 \mathrm{mg} / \mathrm{g}$ for sinapin and for sinapic acid to $0.3 \mathrm{mg} / \mathrm{g}$ and $1.4 \mathrm{mg} / \mathrm{g}$ for the protein isolate UF and the protein concentrate IP, respectively. In contrast to our findings, Puratein ${ }^{\circledR}$ and Supertein ${ }^{\circledR}$ had significantly higher phenolic acid contents of $0.4 \%$ and $0.3 \%$, respectively (Mejia et al., 2009a, 2009b). Inositol phosphates including phytic acid were extensively removed during ultrafiltration resulting in a protein isolate with a content of $0.2 \%$, whereas the content of inositol phosphates was $5.1 \%$ in the protein concentrate IP being higher than that of Puratein ${ }^{\circledR}$ and Supertein ${ }^{\circledR}$, respectively (Mejia et al., 2009a, 2009b). However, similar contents of phytic acid in isoelectric precipitated isolates have been reported previously (Dev, 1986). Therefore, further developments should aim at reduction of phytic acid in the protein concentrate IP.

Furthermore, the techno-functional properties of the potential ingredients were evaluated according to standardized methods (Tab. 4).

The techno-functional properties of the rapeseed protein products were similar or even superior to those of soy protein isolate and egg proteins, respectively. In detail, the protein solubility at $\mathrm{pH} 7$ was $78 \%$ for the protein isolate and $14 \%$ for the protein concentrate. The low protein solubility of the concentrate is related to the isoelectric point of the protein fractions at $\mathrm{pH} 6.3$ being close to $\mathrm{pH}$ 7. Protein solubility rises as the distance between the adjusted $\mathrm{pH}$ and the isoelectric point of the proteins increases.

Particularly, the protein isolate UF had an excellent emulsifying capacity of $810 \mathrm{ml} / \mathrm{g}$, which is about $80 \%$ of that of sodium caseinate - a common emulsifier in foods. Besides the protein solubility, also the foaming properties of the isolate were excellent being even comparable to those of egg yolk protein and hen egg white powder. Similar results were also reported previously for isoelectric precipitated and ultra-filtrated rapeseed proteins (Yoshie-Strak et al., 2008). In contrast to these findings, the emulsifying capacity and the foaming properties were considerably lower for the protein concentrate IP, which is most likely related to the low solubility at $\mathrm{pH} 7$ as protein solubility is supposed to directly influence the other functional characteristics of proteins (Cheftel, 1992). The water and oil binding capacities of the rapeseed protein concentrate IP and isolate UF also varied significantly. The protein concentrate IP revealed a water binding capacity of $1.0 \mathrm{ml} / \mathrm{g}$ and an oil binding capacity of $2.7 \mathrm{ml} / \mathrm{g}$, whereas the protein isolate UF had water and oil binding capacities of $1.6 \mathrm{ml} / \mathrm{g}$ and $1.3 \mathrm{ml} / \mathrm{g}$, respectively. Due to their excellent functional properties of both rapeseed protein ingredients, promising application in different food systems could be expected.

\section{Application ranges of the rapeseed ingredients}

To show the high potential of rapeseed proteins, the protein concentrate IP and the protein isolate UF were applied in sausages and mayonnaise. The cooking loss of sausages was reduced to $7.6 \%$ and $7.8 \%$ by adding rapeseed protein isolate UF and protein concentrate IP, respectively, or sodium caseinate $(7.0 \%)$ in comparison to the reference products $(8.6 \%)$. Therefore, both ingredients can be added to sausages to reduce the cooking losses as an alternative to sodium caseinate. The sensory evaluation of the sausages revealed similar results for the conventional, the sodium caseinate enriched and the rapeseed protein enriched sausages. Comparing the two rapeseed protein preparations the sausages containing rapeseed protein isolate UF were rated slightly higher compared to the sausages comprising the protein concentrate IP. This slight difference might be attributed to the presence of higher amounts of secondary plant metabolites (inositol phosphates, glucosinolates and sinapics) in the concentrate as shown in Table 3.

Furthermore, mayonnaise was prepared utilizing both rapeseed protein ingredients as substitute for egg proteins and compared to conventional products. Directly after preparation and after storage for 8 weeks, the firmness of the emulsions, the sensory properties and the color were evaluated using standardized methods. Mayonnaises containing rapeseed protein isolate UF exhibited similar firmness after preparation compared to the reference product, but were significantly firmer after storage. Mayonnaises prepared with the protein concentrate IP became softer during storage. The sensory evaluations revealed no significant differences between the investigated

Table 4. Comparison of techno-functional properties of rapeseed protein isolate UF and rapeseed protein concentrate IP with commercially available protein products.

\begin{tabular}{lccccccc}
\hline & $\begin{array}{c}\text { Protein } \\
\text { solubility } \\
\text { at } \\
\mathrm{pH} 7 \%)\end{array}$ & $\begin{array}{c}\text { Water } \\
\text { binding } \\
\text { capacity } \\
(\mathrm{ml} / \mathrm{g})\end{array}$ & $\begin{array}{c}\text { Oil } \\
\text { binding } \\
\text { capacity } \\
(\mathrm{ml} / \mathrm{g})\end{array}$ & $\begin{array}{c}\text { Emulsifying } \\
\text { capacity } \\
\text { (ml oil/g } \\
\text { product) }\end{array}$ & $\begin{array}{c}\text { Foaming } \\
\text { activity }(\%)\end{array}$ & $\begin{array}{c}\text { Foam } \\
\text { stability (\%) }\end{array}$ & $\begin{array}{c}\text { Foam } \\
\text { density (g/L) }\end{array}$ \\
\hline Protein isolate UF & 78 & 1.6 & 1.3 & 810 & 2940 & 96 & 37 \\
Protein concentrate IP & 14 & 2.7 & 1.0 & 465 & 1276 & 74 & 77 \\
Hen egg white powder & 95 & - & - & - & 1535 & 98 & 65 \\
Egg yolk powder & 66 & - & - & 490 & No foaming & No foaming & No foaming \\
Soy protein isolate & 26 & 6.0 & 1.8 & 605 & - & - & - \\
\hline
\end{tabular}


mayonnaises, except the color. All rapeseed protein containing mayonnaises were found to be more brownish.

\section{Conclusions and perspectives}

The fractionizing of rapeseed kernels and press cakes by extractive processes opens a lot of possibilities for new vegan protein ingredients. In this study, different processes have been investigated to identify the right process configuration and parameters for achieving highly functional protein ingredients from rapeseed for the use in challenging food applications such as sausages, bakery products or mayonnaise.

The NAPUS process including hulling of the rapeseed kernels followed by an aqueous-alcoholic-extraction resulted in light colored concentrates with protein contents of about $60 \%$. Although, the first appearance is good such aqueous-alcoholic concentrates showed poor functional properties due to the denaturation effects caused by the application of a mixture of water with isopropyl alcohol. This protein damage can only be partly compensated by re-functionalization using high pressure homogenizing, but the resulting solubility, emulsifying and foaming properties were not comparable to conventional food ingredients such as milk, casein or egg. Another weak point of concentrates from aqueous-alcoholic-extraction is presence of quite high amounts of secondary plant metabolites and flavor active components that lead to a brown color as well as an oily and strawy off-flavor, respectively. So the content of this rapeseed protein ingredient is limited to about $2 \%$ in sausages. As flavor and color are not as relevant for bakery applications, a $100 \%$ substitution of egg can be reached without any differences in volume expansion for pound cakes.

Protein ingredients from rapeseed with improved sensory and techno-functional properties could be achieved by aqueous extraction followed by adsorption of the extracts with specific adsorbtion resins. This process strategy enables the production of protein isolates with reduced off-flavors and optimized functional characteristics, because of mild processing conditions lacking protein denaturation. The isolates showed emulsifying properties that are comparable with casein and foaming properties better then hen egg white powder. Applications in sausages and mayonnaise did not reveal any weaknesses in texture, color and taste for the isolate compared to the conventional casein and egg-containing recipes. This shows the strength of rapeseed proteins compared e.g. to soy, were even native protein isolates do not show comparable emulsifying and foaming properties.

Therefore, future research should focus on improving the sustainability of the process by reducing water and adsorber consumption in order to receivehigh quality food ingredients from rapeseed at feasible costs.

Acknowledgements. The investigations have been carried out in the context of NAPUS 2000 and "Fraktionierung Raps-Presskuchen". NAPUS 2000 was a promoted project to the topic "Nutrition - Innovative Processes for Food Production", sponsored by BMBF. "Fraktionierung Raps-Presskuchen was a promoted project on the development of a fractionation process for rapeseed press-cake aiming the production of high quality protein products sponsored by the Bavarian research foundation. Additionally, the authors would like to thank all participating project partners for their support.

\section{References}

Alfa Laval AB (Alfa). Protein concentrate for human consumption - prepared from Brassica species esp. Rapeseed, or crambe abyssinica.

Barbin DF, Natsch A, Muller K. 2011. Improvement of functional properties of rapeseed protein concentrates produced via alcoholic processes by thermal and mechanical treatments. J. Food Process. Pres. 35: 369-375.

Behlau L. 1990. Verfahrenstechnische optimierung der proteingewinnung aus rapssaaten. Technische Universität München, München.

Bell JM. 1984. Nutrients and toxicants in rapeseed meal - a review. $J$. Anim. Sci. 58: 996-1010.

Bell JM. 1993. Factors affectrngthe nutritional value of canola meal: A review. Can. J. Animal Sci. 73: 679-697.

Borcherding AM, C, Mozer S, Müller K, Natsch A, Schweinberger J, Wüsche A, Wild F. 2005. Napus 2000: Gesunde lebensmittel aus transgener rapssaat - teilprojekt 11: Fraktionierung von transgener rapssaat und gewinnung hochwertiger speicherproteine für den einstz in lebensmitteln mittels simultaner öl- und proteingewinnung. Fraunhofer Gesellschaft zur Förderung der angwandten Forschung.

Cheftel JCC, JL, Lorient D. 1992. Lebensmittelproteine: Biochemie funktionelle eigenschaften - ernährungsphysiologie - chemische modifizierung. German Edition. Hamburg: Behr's Verlag.

Cheryan M. 1980. Phytic acid interactions in food systems. Crc. Cr. Rev. Food Sci. 13: 297-335.

Dev DKM, KD. 1986. Functional properties of rapeseed protein products with varying phytic acid contents. J. Agric. Food Chem. 34: 775-780.

Frische R, Best B, Hegwein K, Ricker R, Brunner K. 1996. Recovery of natural fats, oils or waxes from natural mixture - by forming mixt. Of comminuted starting material, water and water-miscible organic solvent, and centrifuging.

Graf E. 1983. Applications of phytic acid. J. Am. Oil Chem. Soc. 60: 1861-1867.

Harland BF, Morris ER. 1995. Phytate - a good or a bad food component. Nutr. Res. 15: 733-754.

Huang AHC. 1994. Structure of plant seed oil bodies. Curr. Opin. Struc. Biol. 4: 493-498.

Jones JD. 1979. Rapeseed protein-concentrate preparation and evaluation. J. Am. Oil Chem. Soc. 56: 716-721.

Liu RFK, Thompson LU, Jones JD. 1982. Yield and nutritive-value of rapeseed protein-concentrate. J. Food Sci. 47: 977-981.

Mejia LA, Korgaonkar CK, Schweizer M, Chengelis C, Marit G, Ziemer E, Grabiel R, Empie M. 2009a. A 13-week sub-chronic dietary toxicity study of a cruciferin-rich canola protein isolate in rats. Food Chem. Toxicol. 47: 2645-2654.

Mejia LA, Korgaonkar CK, Schweizer M, Chengelis C, Novilla M, Ziemer E, Williamson-Hughes PS, Grabiel R, Empie M. 2009b. A 13-week dietary toxicity study in rats of a napin-rich canola protein isolate. Regul. Toxicol. Pharm. 55: 394-402.

Mieth G, Schwenke KD, Raab B, Bruckner J. 1983. Rapeseed - constituents and protein products .1. Composition and properties of proteins and glucosinolates. Nahrung-Food 27: 675-697.

Müller K. 2010. Entwicklung eines fraktionierungsverfahren für raps-presskuchen aus dezentralen ölmühlen zur gewinnung hochpreisiger proteinprodukte. Fraunhofer-Istitut für Verfahrenstechnik und Verpackung IVV, Freising. 
Murphy DJ. 1993. Structure, function and biogenesis of storage lipid bodies and oleosins in plants. Prog. Lipid. Res. 32: 247-280.

Naczk M, Diosady LL, Rubin LJ. 1985. Functional-properties of canola meals produced by a 2-phase solvent-extraction system. J. Food Sci. 50: 1685.

Naczk M, Diosady LL, Rubin LJ. 1986. The phytate and complex phenol content of meals produced by alkanol-ammonia hexane extraction of canola. Lebensm. Wiss. Technol. 19: 13-16.

Naczk M, Shahidi F. 1989. The effect of methanol ammonia watertreatment on the content of phenolic-acids of canola. Food Chem. 31: 159-164.

Porres JM, Etcheverry P, Miller DD, Lei XG. 2001. Phytase and citric acid supplementation in whole-wheat bread improves phytatephosphorus release and iron dialyzability. J. Food Sci. 66: 614 619.

Rubin LJ, Tzeng YM, Diosady LL. 1988. Ultrafiltration in rapeseed processing. Abstr. Pap. Am. Chem. S 195: 82-AGFD.

Schwenke KD. Rapeseed protein. In: New and developing sources of food proteins. London: Chapman \& Hall, 1994.

Schwenke KD, Raab B, Plietz P, Damaschun G. 1983. The structure of the 12s-globulin from rapeseed (brassica-napus 1). NahrungFood 27: 165-175.

Schwenke KD, Raab B, Uhlig J, Tkocz H, Behlke J, Bottger M, Freimuth U. 1973. [seed proteins. 3. Isolation and characterization of albumin of sunflowers and rapeseed]. Nahrung 17: 791809.
Serraino MR, Thompson LU. 1984. Removal of phytic acid and protein phytic acid interactions in rapeseed. Journal of agricultural and food chemistry. J. Agric. Food Chem. 32: 38-40.

Shahidi F, Daun JK, DeClercq DR. 1997. Glucosinolates in brassica oilseeds: Processing effects and extraction. ACS Sym. Ser. 662: 152-170.

Sosulski F. 1979. Organoleptic and nutritional effects of phenoliccompounds on oilseed protein products - review. J. Am. Oil Chem. Soc. 56: 711-715.

Synge RLM. 1975. Interactions of polyphenols with proteins in plants and plant products. Qual Plant 24: 337-350.

Thompson LU. 1987. Reduction of phytic acid concentration in protein isolates by acylation techniques. J. Am. Oil Chem. Soc. 64: $1712-1717$.

Thompson LU, Liu RFK, Jones JD. 1982. Functional-properties and food applications of rapeseed protein-concentrate. J. Food Sci. 47: 1175-1180.

Wäsche A. 2001. Simultane öl- und proteingewinnung bei raps. Berlin: Technische Universität Berlin.

Yoshie-Stark Y, Wada Y, Schott M, Wasche A. 2006. Functional and bioactive properties of rapeseed protein concentrates and sensory analysis of food application with rapeseed protein concentrates. Lwt-Food Sci. Technol. 39: 503-512.

Yoshie-Strak Y, Wada Y, Waesche A. 2008. Chemical composition, functional properties, and bioactivities of rapeseed protein isolate. Food Chem. 107: 32-39.

Cite this article as: Daniela Von Der Haar, Klaus Müller, Stephanie Bader-Mittermaier, Peter Eisner. Rapeseed proteins - Production methods and possible application ranges. OCL 2014, 21(1) D104. 